\title{
EDITORIAL
}

\section{The Teaching of Anaesthesia}

ONE BECOMEs increasingly aware that while much thought is given by clinical teachers of medicine generally to the problem of what to teach students at all levels of training, much too little thought is given to how to teach them. This general observation applies as well to teachers of anaesthesia as to those in other branches of the profession of medicine.

Our modern undergraduate curriculum has become so crowded that no teacher in a medical school today could pretend to convey to his students a detailed knowledge of his particular branch of medical practice. If a detailed and particular knowledge is impracticable, what type of training, then, should the undergraduate recelve?

It would appear that the greatest service which the teacher in a special field. of medicine could provide to a student would be to assist him to appreciate the problems related to that spiecial field in terms of the physiology, pharmacology, brochemistry and anatomy which he already knows (or'should know), and to relate these special problems in a logical way to the knowled ge of general medicine which he is presently acquuring, and which should also je built systematically on his knowledge of the basic sciences. In his contacts with the undergraduate the teacher must emphasize the "what" and the "why" of his subject, and, so far as possible, train his student by the process of reasoning to arrive at the "how" of any situation. "Know-how" may be admirable in, a technician, but a physician can only be competent when he also has "know-why."

The methods of training of the post-graduate student in the specialty require still further consideration. The older generation of anaesthetists who are now gradually retiring from the scene have grown with the specialty, and have brought us' from the rag-and-bottle and whiff-of-gas era to the complexities of modern anaesthesia through decades of progress, when their long experience and developed judgment led them easily from one step to the next. The problem of the teacher of the fledgling anaesthetist today is to conduct his young charge through this same progress in the space of two or three years This process can only be successful if again, "whatp" and " $w h y p$ " are the dominant themes in the teaching, the problems of "how" standing not alone as technical feats but as logical answers derived from the other factors through reason.

There have been widely divergent views of the best method of achieving this logical organization of our teaching. Some teachers would consider clinical anaesthesia purely as applied pharmacology, and the application in the operating room of the methods learned in and transferred from the laboratory as the logical and adequate solution. We are aware that this programme in practice has produced many admirable scientists who are poor clinical anaesthetists. Conversely, we are aware of many excellent clinical anaesthetssts who are so because of superior intuition and practised judgment, and who are unable to explain their activities in sound or logicall terms.

Surely the best we can do for the developing anaesthetsst is to give him the 
best of these apposite types. He must be offered a firm foundation in basic medical science, and wide experience in the operating room. He must, moreover, be required in his clinical work to explain and justify himself at every step. Only in this way can he hope to achieve in his few years of training the standard developed by his predecessors through many decades. Only in assuring such a training does his teacher adequately fill his role.

\section{On the Introduction of a New Drug: F'luothane}

We have previously in this Journal discussed the principal requirements for the evaluation of new drugs in anaesthesia (1) and the philosophy of the investigation and reporting of clinical trials of new drugs (2). In this issue we are privileged to present at one time reports of several different and independent investigations of the clinical use of a new volatile anaesthetsc agent, Fluothane.

It appears evident that Fluothane combines desirous and admirable properties with potentially dangerous activity which may produce fatalıtes in the hands of the unwary. Whle such a combination of properties is not new to the trained anaesthetist, there has in the past been a regrettable tendency for some enthusiasts to embark on the wholesale use of a new drug or a new method, without due regard to the aspects of safety. When this occurs the tragic results of poor judgment are too often attributed to the drug or the method, in general terms.

We hope sincerely that the simultaneous presentation to our readers of diverse reports on the clinical use of Fluothane will help to provide the basis of a rational and careful introduction of this drug to clinical practice.

\section{REFERENCES}

1 Melville, K J. Editorial Evaluation of New Drugs in Anaesthesia Canad Anaesth. Soc J, 2 I (1955)

2 Editonal New Drugs Canad Anaesth Soc J, 3289 (1956) 


\section{EDITORIAL}

\section{L'ENSEIGNEMENT DE L'ANESTHÉSIOLOGIE}

ON PEUT se rendre compte de plus en plus que les professeurs de clinique médicale, de façon générale, s'attardent davantage sur le problème de savoir quoi enseigner aux différents niveaux de l'entraînement que sur le problème de savoir comment enseigner Cette remarque générale concerne aussi bien les professeurs d'anesthésiologie que ceux des autres spécralités de la profession médicale.

Notre programme universitaire moderne est devenu tellement chargé qu'aucun profèsseur d'une école de médecine ne peut prétendre, aujourd'hui, servir à ses élèves les connarssances détaillées de sa spécialité dans la pratique médicale.

S'll est impossible de fournir des connaissances particulières détaillées, quelle sorte d'entraînement, alors, doit recevoir l'étudiant en médecine?

Il semblevait que le plus grand service que le professeur d'une spécialité médıcale péut rendre à un élève seratt d'aider cet élève à étudier les problèmes de cette spécialıté en rapport avec la physiologie, la pharmacologie, la biochimie et l'anatomie qu'il sart déjà (ou qu'il devratt savour) et do faire la relation, de façon logique, de ces problèmes spéciaux avec les connaissances de la médecine générale, connaissances qu'íl est en train d'acquérir et qui, elles-mêmes, systématrquemen't, devraiert être basées sur ses connaissances des sciences de base. Au cours dè ses entrejens avec l'élève, le professeur doit insister sur le "quoi" et le "pourquo" du sujet et, autant que possible, habituer l'élève" à raisonner pour en venrr au "comment" en toute circonstance. "Savoir comment" peut être très précleux pour un technicien, mass pour qu'un médecin soit compétent, il faut qu'il sache également "pourquoi"

Les façoǹs d'enseigner aux élèves du cours post-universitaire d'une spécialtté demandent encore plus d'attention La génération des anesthésistes plus âgés qui commencent actuellement à se retrer de la scène mais qui ont grandi dans le spécialité nous ont transportés de l'ère de la compresse et de la bouteille et de la bouffée de gaz aux problèmes complexes de l'anesthésie moderne en sulvant des décades de progrès alors que leur longue expérience et leur souple jugement leur ont permis dı passer facilement d'un pas à' l'autre. Aujourd'hui, le problème du professeur envers le futur anesthésiste est dé lui faire parcourir la même route en deux ou trois ans. Cette façon de faire ne peut conduire au succès qu'à la condition que les "quor" et les "pourquor" demeurent les thèmes dominants de l'enseignement, que les problèmes du "comment" ne dimeurent pas seulement des tours de force de la technique, mais des réponses logiques découlant des autres facteurs par l'intermédiaire de la raison.

Il a existé de grandes divergences d'opinion au sujet de la meilleure méthode de réaliser cette organssation logique de l'enseignement. Certains professeurs auraient tendance à considérer l'anesthésie clinıque uniquement comme de la pharmacologie appliquée et l'implantation des méthodes apprises au laboratoire et apportées à la salle d'opération comme une solution logique et adéquate. En pratique, nous réalisons que ce programme a produit plusieurs hommes de 
science distnngués mais de piètres anesthésistes cliniques. Par contre, nous connaissons de nombreux anesthésistes cliniques de prenaière qualité dont les capacités sont dues à une intution supérieure et à̀ un jugement pratuque mais qui sont incapables d'expliquer leurs décisions en cles termes précis et logiques.

Sans doute, le mieux à faire pour l'anesthésiste en formation, c'est de lui donner la mellleure part de ces deux types opposés. On doit lui faire acquérir une formation solide dans les sciences de base médicale et une grande expérience dans la salle d'opération De plus, on doit exiger de lui, au cours de son travall clinique, l'explication et la justification de tous ses gestes. C'est de cette façon seulement que l'on peut espérer réaliser, chez eux, en quelques années d'entraînement le niveau atteint par leurs prédécesseurs au cours de plusieurs décades. Puis, c'est seulement en réalisant un entraînement de cette qualité que leur professeur remplit adéquatement son rôle.

\section{Au sUjeT DE L'ADMission d'Un NOUVEAU MÉdICAMENT: Fluothane}

Antérieurement, dans ce même Journal, nous avons énuméré les principaux facteurs à étudier pour évaluer des médicaments nouveaux en anesthésie (1) et exposé la philosophie qui doit présider à la recherche et au reportage des épreuves cliniques de ces nouveaux médicaments (2). Dans ce numéro-ci, nous sommes heureux de présenter en même temps les résultats dé plusieurs recherches différentes et indépendantes sur l'usage clinıque d'un novivel agent anesthésique volatile, Fluothane

Il semble manifeste que le Fluothane associe de précieuses et désirables qualités à une activité éventuellement dangereuse pouvant entraîner des morts dans les mains de celui qui n'est pas averti. Bien que l'association de semblables propriétées ne soit pas nouvelle pour l'anesthésiste expérimenté, on a constaté, dans le passé, chez certains enthousiastes, une regrettable tendance à employer à tout hasard un nouveau médicament ou une nouvelle méthode, sans considérer le point de vue de sécurité. Dans cette occurrence, les résultats tragiques du manque de jugement retombent souvent, de façon générale, sur le médicament ou la méthode.

Nous avons une ferme confiance que la présentation simultanée, à nos lecteurs, de plusieurs résultats sur l'emplor clinique du Fluothane contribuera à établir une base pour l'admission progressive et prudente de ce nouveau médicament dans la pratique clinque.

\section{BIBLIOGRAPHIE}

1. Melville, K. J. Editonal: Evaluation of New Drugs in Anaesthesia. Canad. Anaesth Soc. J, 2. 1 (1955)

2 Editorial New Drugs Canad Anaesth Soc J, 3289 (1956) 